学術論文

\title{
電池フリーIoT の実現に向けた磁歪式振動発電デバイスの量産構造の提案
}

\section{Proposal of Mass-Production Structure of Magnetostrictive Vibrational Power Generator for Battery-Free IoT}

\author{
上野 敏幸(正員)
}

Toshiyuki UENO (Mem.)

\begin{abstract}
Author proposes mass production structure of magnetostrictive vibrational power generator for battery- free IoT. This is based on a lamination of Fe-Ga alloy and a magnetic material (part), with a coil wound. This lamination is formed as a part of a U-shaped frame yoke with a permanent magnet attached. The magnetic part has moderate rigidity and is in a state of magnetic saturation. When the lamination is bent by an external force, the uniform stress generated in $\mathrm{Fe}-\mathrm{Ga}$ changes the magnetic flux due to the Inverse magnetostrictive effect, and electromotive force proportional to time differential of the interlinking magnetic flux is generated in the coil. Compared with our conventional parallel beam type, the number of turns of the coil can be increased more than twice, and the assembly is easy and durability is high. The prototype using a Fe-Ga plate of $4 \times 0.5 \times 16 \mathrm{~mm}^{3}$ generated maximum power of 1 $\mathrm{mW}$ at $28.4 \mathrm{~Hz}$ and $0.075 \mathrm{G}$ vibration, and succeeded wireless signal transmission with one free vibration.
\end{abstract}

Keywords: vibrational power generator, magnetostrictive material, Fe-Ga alloy, lamination, mass production. (2017年3月17日受付，2017年10月16日再受付)

\section{1 緒言}

振動発電は，振動や日常にある小さな動きから電気 エネルギーを取り出す極めて汎用性の高い技術である。 これが実用化できると，電池のいらない無線センサシ ステムが実現する。橋梁やタービン，生産機械など, 振動を電源に, 歪みや温度, 周波数の情報を無線送信 することで，その状態をメンテナンスフリーで監視で きる。またボタンを押す，ドアや空を開くなど，人や モノの動きで発電し，これを知らせることで防犯や見 守りに役立つ。IoT（モノがインターネットにつながる） の大きな課題は電池交換である。モジュールが数個な らいざしらず, 百個, 千個となるとその電池交換は面 倒で，振動や動きを電源に利用できれば，この問題は 解決する。一方, 振動発電として代表的な圧電セラミ ックスは脆性材料で耐久性に懸念があり，また内部抵 抗が高く負荷から電流を取り出すのが難しい。また発 生電力が小さく, ミリ, サブミリワットの実用的な電 力をつくりには相当の大きさが必要である[1]。

筆者が提案する磁歪式は, 鉄系の磁歪材料[2]を利用 し, 堅牢で振動から高効率の発電を行うのが特徵であ る。デバイスの出力抵抗は小さく, 電流（電力）を取 り出すのにも適する。以上, 磁歪式は振動発電の従来

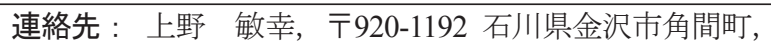
金沢大学理工研究域電子情報学系 e-mail: ueno@ec.t.kanazawa-u.ac.jp
の問題を解決し, 電池不要の無線センサひいては IoT の実現に貢献する。筆者は，この実用化を大きく推進 すべく, 今回, 低コスト, 高感度, 高出力の特徴を備 えるデバイスを考案した。本論文では，その構造と発 電原理, 設計方針, 原理検証実験と試作評価の結果を 述べる。

\section{2 デバイス構造と発電原理}

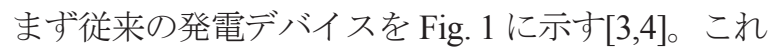
はコイルを巻いた磁歪素子と磁性体の平行梁を基本に する。フレームは平行梁を構成する磁性体, これにつ く自由端, 固定端のU 字型の一体で形成され, フレー ムの内側には磁気バイアスを付与する永久磁石が配置 される。素子は，はんだ，または溶接でフレームに強 固に接合されており，振動時，フレームの開口部が開 閉する屈曲変形が生じ, 逆磁歪効果で素子の磁束が増 減することで発電が行われる。この構造の問題点とし て, コイルの層厚が平行梁の空隙で制限され, 例えば 電圧を上げようとするとコイルの線径を小さくする必 要がある。つまり発生電力を向上するのが難しい。

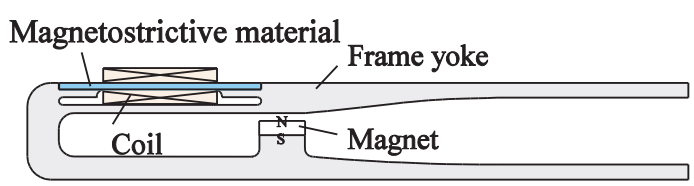

Fig.1 Configuration of conventional device. (parallel beam structure) 
また素子にコイルを巻きフレームに接合するため，そ の熱がコイルに伝わり被覆が溶ける場合がある。更に は，平行梁を構成するには，フレームに溝や段差を設 ける必要がある。現状, フレームの成型はワイヤー放 電加工で行い，実験室レベルの試作では問題ないが, コストと時間が掛かることで量産には不向きである。

以上の問題を解決する構造を考案した[5]。その構造 をFig.2に示寸。フレームは磁性体の板材より成型し， 平行梁は磁歪素子とフレームの積層梁とする。まず Fig.2 上図のフレームの展開図を板材より打ち抜き加 工などで切り出す。その後, これに曲げ加工を施しU 字型にする。このフレームに Fig.2 下図のように板状 の素子を接合，一部に積層部を構成し，端部よりコイ ルを挿入し, 積層部の直上に固定する。最後に永久磁 石をフレームの空隙部に配置することで完成する。な お磁石とフレーム間に, 振動時, フレームの変形に影 響しないよう一定の空隙をあける。

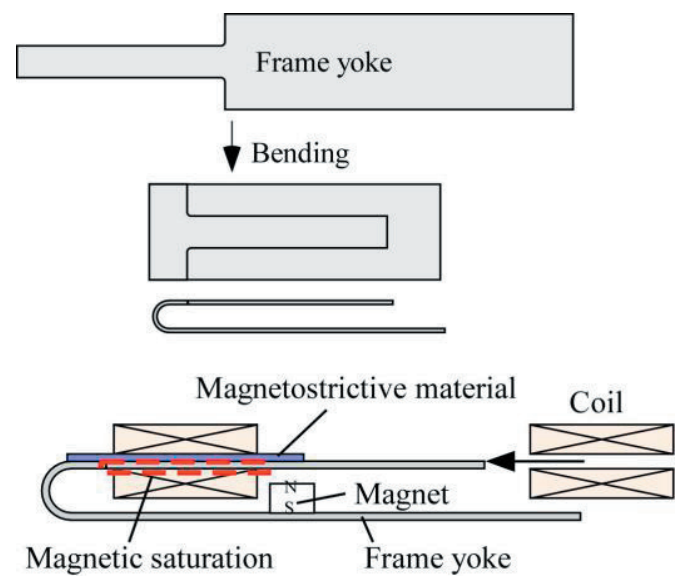

Fig.2 Fabrication of frame yoke (top) and configuration of proposed device (bottom).
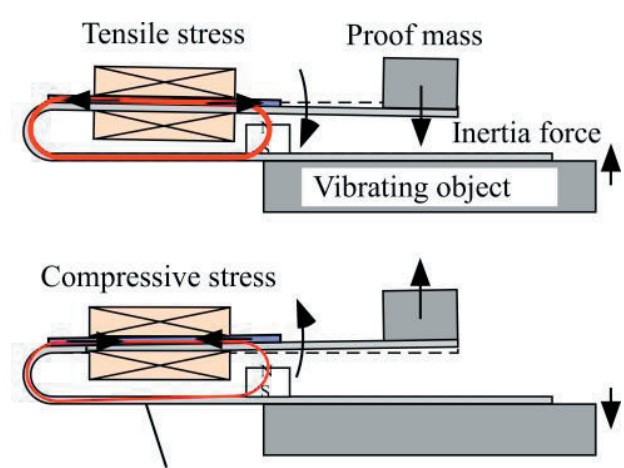

Flux variation by inverse magnetostrictive effect passes through this close loop

Fig.3 Principle of power generation, inertial force applied down (top) and bottom direction (bottom).

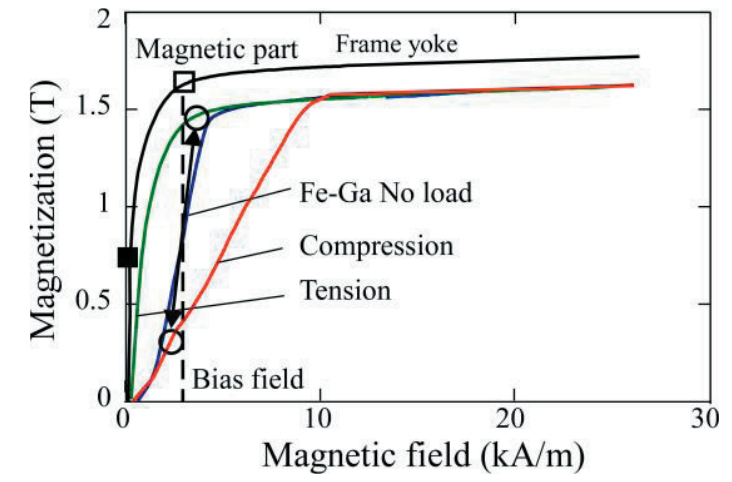

Fig.4 Relationship between M-H curve of Fe-Ga alloy under zero, tension and compressive stress, and frame yoke.

この構造の特徽としてフレームを板材の塑性加工 で成形することで，コストを大幅に低減できる。板材 には冷間圧延材（SPCC）やべーナイト鋼（SC50）な どが利用できる。磁歪素子をフレームに溶接や接着剤 で接合し，必要に応じメッキやコーティングを施し， 後から空心コイルを挿入する組み上げも簡単である。 フレームの要件として, 積層部を構成する部分 (以後, 磁性部と呼ぶ）の形状（幅，厚み）を，屈曲変形時に 素子の長手方向に一様な応力を発生させる，つまり応 力がゼロになる中立軸を磁性部に存在させる，更にこ の部分が磁気飽和の状態になるよう設定する。一方, フレームの磁性部以外で，磁路の役割をする部分は, 磁気飽和しないよう磁性部よりも幅を大きくする。具 体的には磁性部の 2〜3 倍以上にする。

発電原理を Fig.3 に示す。フレームの片端を振動源 に固定し，他端に鍾を取り付け加振する。この時，鍾 の慣性力でフレームの開口部が開閉するようデバイス は変形し，素子の長手方向には，前述の条件で一様な 引張り, 圧縮の応力が発生し, 逆磁歪効果で, その磁 束が増減する。Fig.3 上は, 錘の慣性力が下方向, Fig.3 下は上方向の場合である。素子には永久磁石により， 適度な磁気バイアスが付与されており，一方，磁性部 は磁気飽和の状態にあることで，素子に発生した磁束 の変化は磁歪素子とフレーム, 磁石, ギャップの直列 の閉磁気回路で環流する。ここで磁性部は磁気飽和の ためその磁気抵抗が高く, 素子の磁束の変化分は磁性 部を逆流しない。結果，積層部に巻いたコイルにおい ては，素子で発生する鎖交磁束の時間変化に比例した 起電力が発生することになる。Fig.4 は磁歪素子として $\mathrm{Fe}-\mathrm{Ga}$ 合金とフレームヨークの磁化曲線の関係を模式 的に説明した図である。積層部の Fe-Ga 合金と磁性部 は同じ長さで，磁気バイアスにより点線の磁界が付与 
されており，湾曲時，例えば圧縮と引張りの応力で○ ○の間で Fe-Ga 合金の磁束密度が変化する。一方，磁 性部は口の飽和状態にあり, それ以外の部分はロで,

$\mathrm{Fe}-\mathrm{Ga}$ 合金で発生した $1 \mathrm{~T}$ 程度の磁化変化を通すこと ができる状態にある。この原理では，コイルの層厚を 従来型に対し 2 倍以上大きくできることで, 発生電力 を大きく増加できる。コイル長（抵抗）は，磁歪素子 に巻く従来型に対し, 磁性部の厚み分増加するが, 後 述の試作例にあるよう，その増加率は $10 \%$ 程度であり， それほど大きな影響はない。以上, 本提案の構造は, 量産性と性能の向上の両立を満たすものである。

\section{3 原理検証試験}

本研究では, 平行梁にコイルを巻く発電原理につい て検証した。平行梁の空隙をゼロにしたのが積層で, つまり平行梁は積層の上位概念である。Fig.5 は測定し たデバイスで, SK 材で製作したフレームヨーク $(2 \mathrm{~mm}$ 厚)に $2 \times 0.5 \times 13 \mathrm{~mm}^{3}$ の板状の $\mathrm{Fe}-\mathrm{Ga}$ 合金 $\left(\mathrm{Fe}_{81.6} \mathrm{Ga}_{18.4}\right.$, 福田結晶技研製[6]）の磁歪素子を接合したものである。 磁性部の幅は $2 \mathrm{~mm}$, 厚さ $0.3 \mathrm{~mm}$, 空隙は $1 \mathrm{~mm}$, 永久 磁石は $2 \times 3 \times 1 \mathrm{~mm}^{3}$ のネオジム磁石とした。この素子, 磁性部，素子と磁性部（平行梁全体）のそれぞれに 1 ターンのピックアップコイルを巻き, 加振機で振動さ せた。

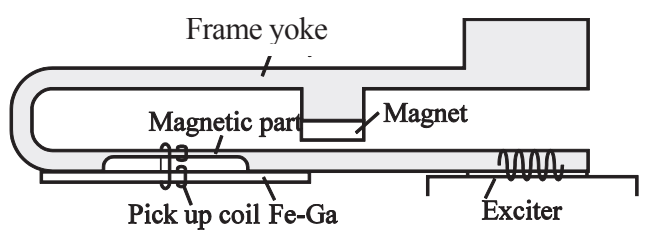

Fig.5 device configuration for experiment.

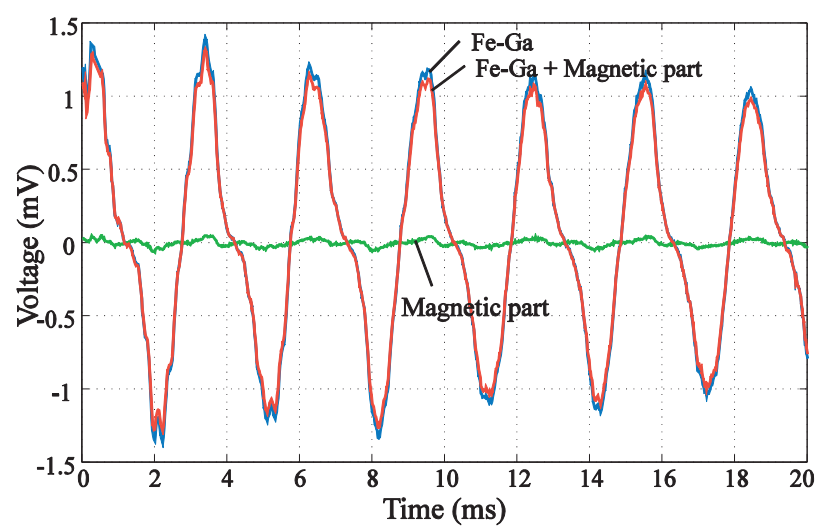

Fig.6 Time response of pick up voltages.

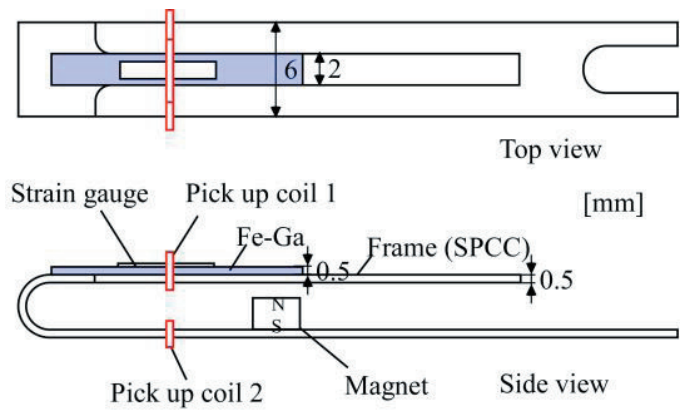

Type A

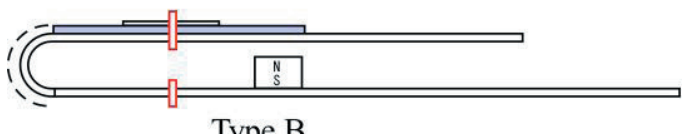

Type B
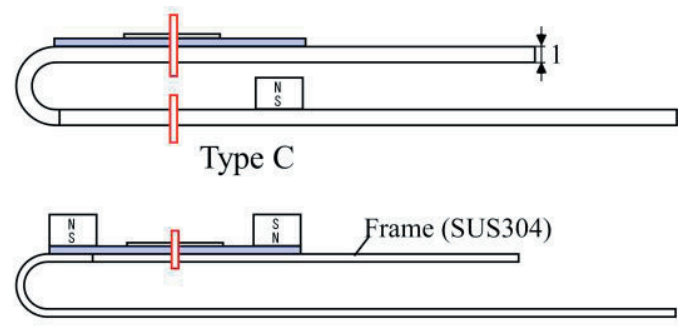

Type D

Fig.7 Device configuration of 4 types.

Fig.6は，発生電圧の時間応答で，Fe-Ga 合金と平行 梁全体の電圧は，ほぼ同じで，一方，磁性部の電圧は 非常に小さいことがわかる。つまり磁性部は磁気飽和 の状態にあり，Fe-Ga 合金で発生した磁束の変化をバ イパスできず，空気と同じと見なせる。以上，磁性部 をまたぎ, 磁歪素子の逆磁歪効果に起因寸る磁束変化 が平行梁に巻いたコイルに起電力を発生する原理が実 証された。

また Fig.7の 4 種類のデバイスについて磁歪素子の歪 と磁束の関係を測定することで提案する構造の優位性 を検証した。素子は共に $2 \times 0.5 \times 16 \mathrm{~mm}^{3}$ の $\mathrm{Fe}$-Ga 合金 （福田結晶技研製）とし，フレームは $\mathrm{A}$ 及び $\mathrm{B}$ では $0.5 \mathrm{~mm}$ 厚の $\mathrm{SPCC}$ 板（磁性）, C では $1 \mathrm{~mm}$ 厚の $\mathrm{SPCC}$ 板，D では SUS304（非磁性）の板より成形した。各 フレームの最大幅は $6 \mathrm{~mm}$ であり, 永久磁石として 2 $\times 3 \times 2 \mathrm{~mm}^{3}$ のネオジム磁石を利用した。

タイプ A が提案する構造で, フレームの磁性部は 2 $\mathrm{mm}$ 幅で磁気飽和し, 磁性部以外の磁路に寄与寸る部 分は $6 \mathrm{~mm}$ 幅で磁気飽和していない。なお本研究では, $\mathrm{Fe}-\mathrm{Ga}$ 合金 (無付加と圧縮・引張り応力付加時) と SPCC 材の B-H 曲線を考慮した FEM による磁場解析を行い 磁歪素子とフレームの磁束密度を計算しており，フレ 一ムの磁気飽和の有無を確かめているが，本稿ではそ 
の結果を割愛する。タイプ B はフレームの屈曲部分 (点 線）まで磁性部と同じ $2 \mathrm{~mm}$ 幅とし, つまり磁性部及 び屈曲部分までが磁気飽和している。タイプ C は, フ レームの厚さを 2 倍にすると共に屈曲部分まで磁性部 と同じ $2 \mathrm{~mm}$ 幅とし, 磁性部及び屈曲部分は磁気飽和 していない。タイプ D のフレームは A と同一の形状で あるが，フレームを非磁性材料（SUS304）とし，これ が磁気回路の役割をしないため, 永久磁石を積層部の 両端に配置し磁気バイアスを与える。なお積層を利用 する従来の発電デバイスのほとんどが D の磁歪素子と 非磁性材料との組み合わせ[7][8]である。各磁歪素子 の中央に歪みゲージを接着し, またタイプ A, B, Cで は積層部とフレームの固定端側にそれぞれ 1 巻のピッ クアップコイルを巻いた。なおタイプ D では積層部の みにピックアップコイルを巻いた。これらを加振機で 励振し, このときの歪み（積層部の変形）と磁束の変 化（ピックアップの電圧を時間積分）の関係を測定し た。その結果を Fig. 8 に示す。
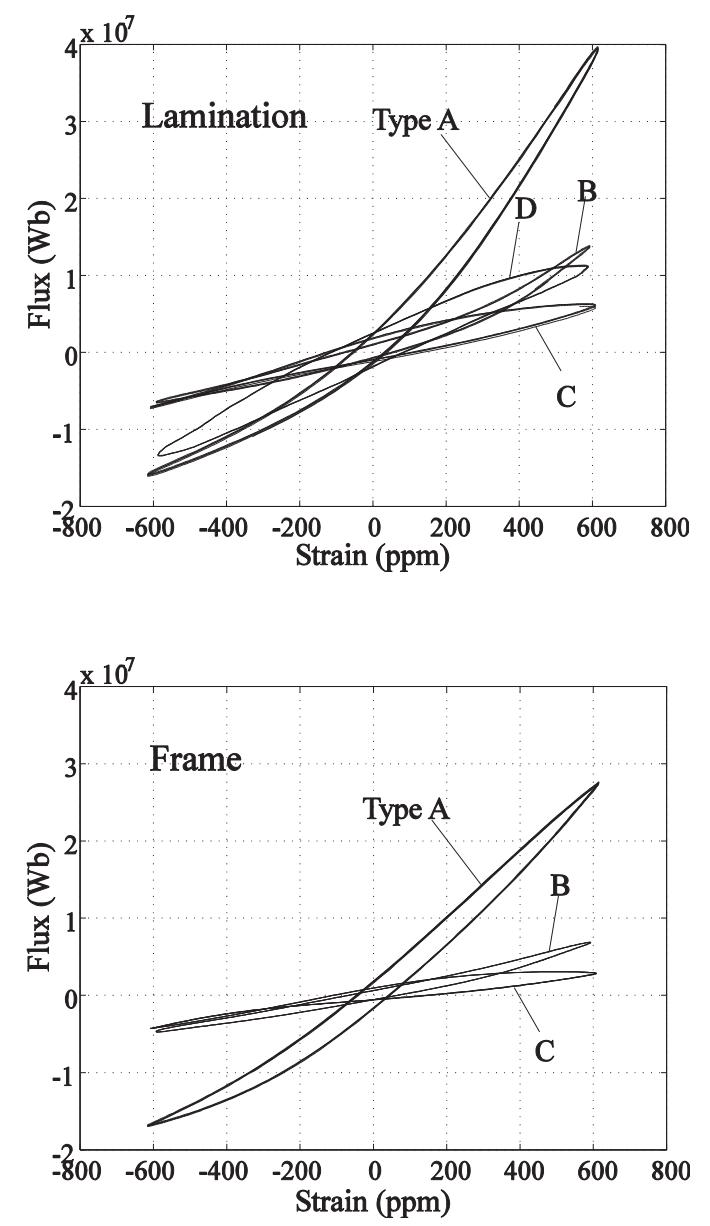

Fig.8 Relationship between strain of Fe-Ga and flux in lamination (top) and frame yoke (bottom).
A の積層部は, B, C, D に比べて同じ歪みに対し磁束 が大きく変化している。また A のフレームの固定端側 についても積層部と同じ程度の磁束の変化が発生して おり, その変化がフレーム閉磁路内を環流しているこ とがわかる。一方, B の磁束の変化が A に比べ積層部 及びフレームの両者で大幅に小さいのは, 磁性部及び これに続く屈曲部までが磁気飽和し, 変化を促寸閉磁 路の役割をしないためである。また C の磁束の変化が 積層部及びフレームの両者で大幅に小さいのは, 磁性 部が磁気飽和の状態でないため, 磁歪素子の磁束変化 が磁性部を逆流して素子に戻るという局所的な閉磁路 を形成し，全体で外部に現れる磁束変化を打ち消すた めである。D の磁束の変化が大幅に小さいのは，フレ 一ムが磁束を通さず，B と同じく変化を促す閉磁路を 形成しないためである。以上, 提案する構造の優位性, およびフレームの磁性部を磁気飽和させ，それ以外を 磁気飽和させない設計方針を実証した。

\section{4 発電デバイスの試作評価}

Fig.9 の寸法の発電デバイスを試作し，その特性を評 価した。磁歪素子は $4 \times 0.5 \times 16 \mathrm{~mm}^{3}$ の Fe-Ga 合金

$\left(\mathrm{Fe}_{81.6} \mathrm{Ga}_{18.4}\right.$, 福田結晶技研製 $)$ で, フレームは $0.5 \mathrm{~mm}$ 厚の SPCC 材から成型し, 磁性部の幅は素子と同じ 4 $\mathrm{mm}$, それ以外の幅は $12 \mathrm{~mm}$, 屈曲部の曲率半径は 1.5 $\mathrm{mm}$ とした。また素子とフレームの接合にはエポキシ 系の接着剤を利用した。この積層部に線径 $0.05 \mathrm{~mm}$, 層厚 $2 \mathrm{~mm}$, 長さ $7 \mathrm{~mm}$, 巻き数 3500 ターン, 直流抵 抗 $500 \Omega$ の空心コイルを被せ固定した。なお層厚 $2 \mathrm{~mm}$ は同じ $0.5 \mathrm{~mm}$ の Fe-Ga 合金を利用寸る平行梁式の 2 倍である。またフレームの内側に $4 \times 3 \times 2 \mathrm{~mm}^{3}$ のネオ ジム磁石を配置し，これとフレーム間の空隙を $1 \mathrm{~mm}$ とした。Fig. 10 は試作したデバイスの写真で, フレー ム先端に L 字金具を介し $1.7 \mathrm{~g}, 3.2 \mathrm{~g}, 10.2 \mathrm{~g}$ の錘を取り 付け, これを加振機（SL0505, 旭製作所）に固定し振 動させた。この時の加速度 (加速度ピックアップPV63, リオン)およびデバイスの電圧, 発生電力を測定した。

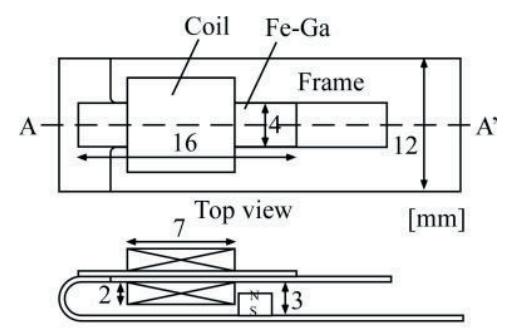

AA' cross-sectional view

Fig.9 Dimension of prototype. 


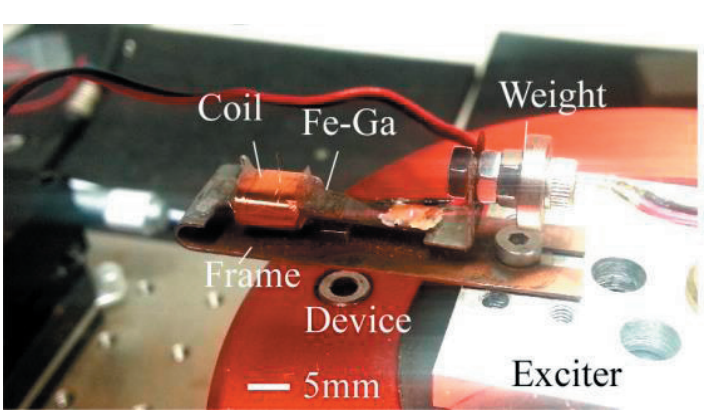

Fig.10 Picture of prototype fixed on exciter.

Fig.11 は白色雑音で加振し, FFT アナライザー （CF-7200，小野測器）で測定した開放電圧 $e$ /加速度 $a$ の周波数応答の結果である。錘がそれぞれ $1.7 \mathrm{~g}, 3.2 \mathrm{~g}$, $10.2 \mathrm{~g}$ の場合, 共振周波数はそれぞれ $89.8 \mathrm{~Hz}, 57.9 \mathrm{~Hz}$, $28.9 \mathrm{~Hz}, \mathrm{Q}$ 值はそれぞれ 185, 196, 195 であった。

錘が $10.2 \mathrm{~g}$ ，周波数 $28.4 \mathrm{~Hz}$ ，加速度 $0.34 \mathrm{~m} / \mathrm{s}^{2}(0.034$ G) $, 0.49 \mathrm{~m} / \mathrm{s}^{2}(0.049 \mathrm{G}), 0.61 \mathrm{~m} / \mathrm{s}^{2}(0.061 \mathrm{G})$ の場合 の電圧波形を Fig. 12 に示す。加速度 $0.049 \mathrm{G}$ で $1 \mathrm{~V}$ の 電圧が発生し, 微小振動で実用的な電圧が取り出せる ことが実証された。Fig. 13 は加速度 $0.75 \mathrm{~m} / \mathrm{s}^{2}(0.075 \mathrm{G})$ の場合の抵抗と電力 (ジュール損) の関係で, 抵抗 500 $\Omega$ 付近で $1.1 \mathrm{~mW}$ の最大電力, $0.39 \mathrm{~mW}$ の実効電力が得 られた。

また錘を $1.7 \mathrm{~g}$ とし, 周波数 $88.7 \mathrm{~Hz}$, 加速度 $3 \mathrm{~m} / \mathrm{s}^{2}$ $(0.3 \mathrm{G}), 6 \mathrm{~m} / \mathrm{s}^{2}(0.6 \mathrm{G}), 9 \mathrm{~m} / \mathrm{s}^{2}(0.9 \mathrm{G})$ の正弦波で 振動させた場合の電圧波形を Fig.14 に示す。加速度 0.9 $\mathrm{G}$ で最大 $5.4 \mathrm{~V}$ の電圧が発生した。加速度 $0.6 \mathrm{G}$ の場合 で，負荷として抵抗を接続し，抵抗と電力の関係を測 定した結果を Fig. 15 に示す。1000 $\Omega$ 付近で，最大電力 $5.1 \mathrm{~mW}$ ，実効電力 $2.0 \mathrm{~mW}$ が得られた。

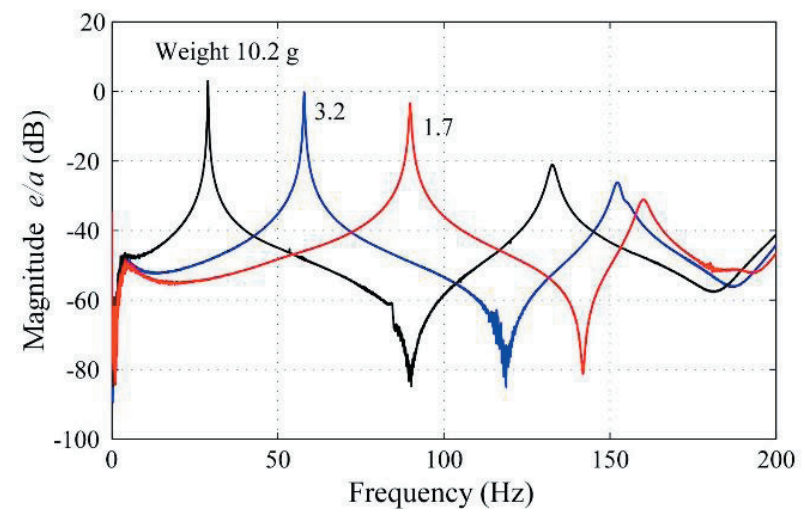

Fig. 11 Frequency response of voltage/acceleration with varied weight.

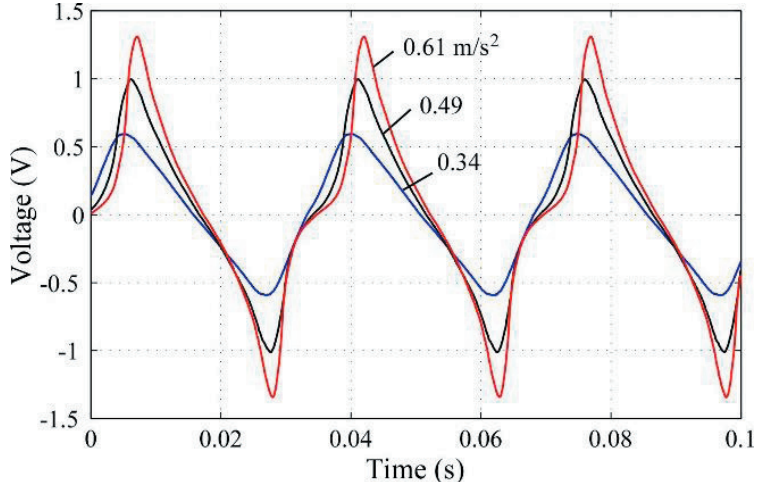

Fig.12 Open voltages (28.4 Hz).

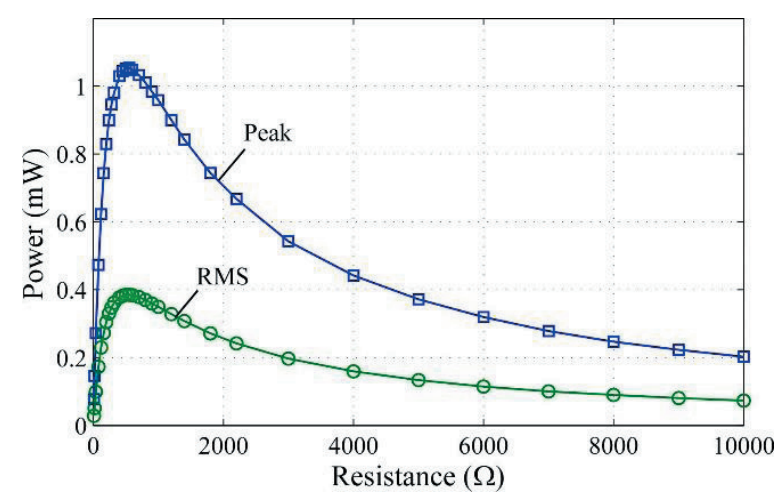

Fig. 13 Power vs. resistance (0.075 G).

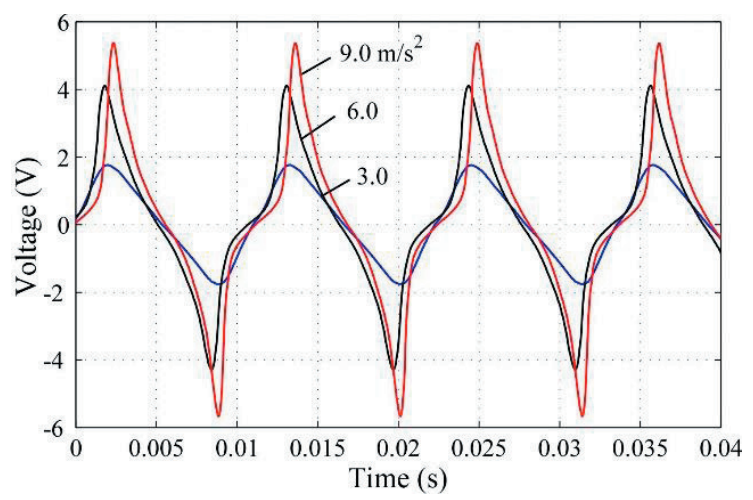

Fig. 14 Open voltages $(88.7 \mathrm{~Hz})$.

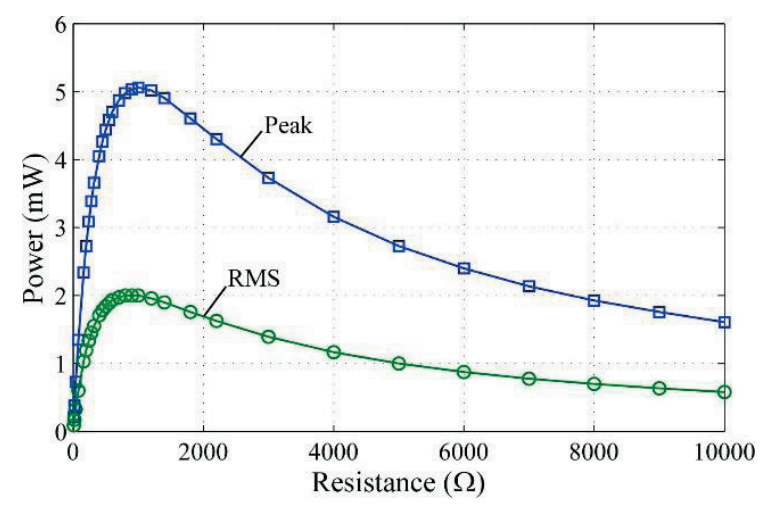

Fig.15 Power vs. resistance (0.6 G). 
なお従来の平行梁型で $6 \times 0.5 \times 13 \mathrm{~mm}^{3}$ の Fe-Ga 合金, 線径 $0.05 \mathrm{~mm}, 1900$ 巻, 層厚 $1 \mathrm{~mm}(283 \Omega)$ のコイル で構成したデバイスの場合[4], $166 \mathrm{~Hz}, 2.5 \mathrm{G}$ の振動で $5.2 \mathrm{~V}$, 最大電力 $9.1 \mathrm{~mW}$, 実効電力 $3.7 \mathrm{~mW}$ が発生する。 電磁誘導では電圧は周波数に比例し, 電力は周波数の 二乗に比例することを考慮すると, 積層型は, 平行梁 型に対し, より小さな磁歪素子で, 電圧と電力を向上 させている。

次に，デバイスを Fig.16のように厚さ $3 \mathrm{~mm}$ のアク リル板にネジで取り付け，手に持った状態で先端を指 で弾いた。これはリモコンの筐体に実装した場合を想 定した動作実験である。なお共振周波数を高めるため 先端に錘は付けていない。この自由振動時の発生電圧 の時間応答を Fig.17 に示す。最大 $27 \mathrm{~V}$ の電圧を発生

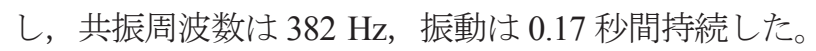
これに倍電圧整流回路，33 $\mu \mathrm{F}$ のキャパシタを介し, リモコンモジュール（IM315TX，インタープラン[9]） に電力を供給したところ，一度弾くことでモジュール が動作し, 無線信号が送信された。以上, 電池不要の リモコンや動きをトリガに情報を送信するデバイスが 可能であることが実証された。

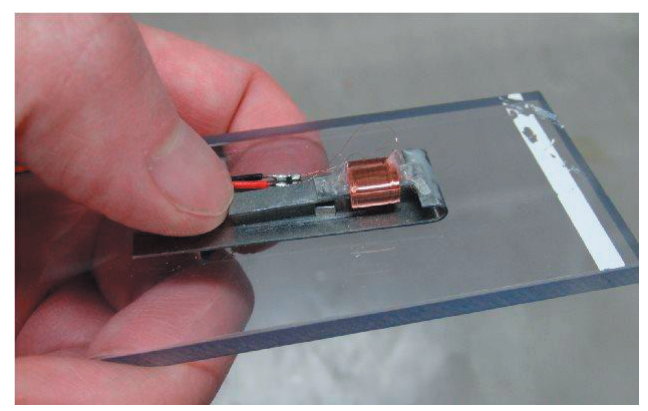

Fig.16 Device prototype fixed acrylic plate.

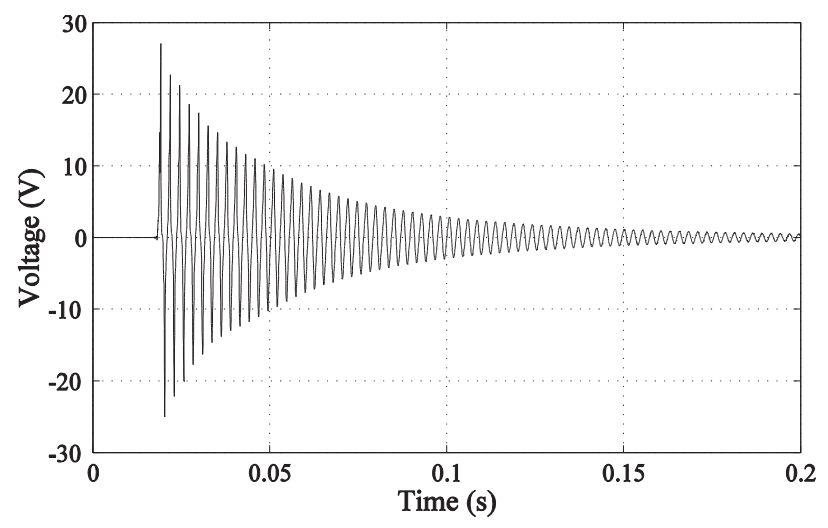

Fig.17 Open voltage excited by finger flicking.

\section{5 結言}

磁歪素子と磁性体の積層を基本にした振動発電デ バイスの新構造について述べた。デバイスはシンプル かつ, 高感度, 高出力で, 環境にある微小な振動や動 きから無線センサや IoT モジュールの自立的動作に十 分な実用的な電圧またミリワットオーダの電力が取り 出せる。耐久性に関しては 1 億回の繰り返し振動後も 性能が劣化しないことを実証している $[10]$ 。現在，複 数の企業で Fe-Ga 合金の量産化研究が進行中で，材料 コストが低下すれば，その単価は数百円程度になりボ タン電池と同等になる。IoT の対象となるモノの数は 500 億個ともいわれ, 無線センサや IoT の電池不要化 には大きな可能性と市場がある。振動を制御するので はなく, 如何に振動を発生させるか。これら構造やシ ステムの知的財産, 電池不要 IoT のビジネスモデルの 確立が急がれる。

\section{謝辞}

本研究はJST CREST「微小エネルギーを利用した革 新的な環境発電技術の創出」（課題番号 JPMJCR15Q1） を受けて行われた。

\section{参考文献}

[1] 安達, 坂本, 圧電コンポジットを用いた振動発電装置の エネルギー変換効率に関する研究，日本機械学会論文集 (C 編)，Vol. 78, No.789, pp.1575-1585, 2012.

[2] J. Atulasimha and A. B Flatau, A review of magnetostrictive iron-gallium alloys, Smart Materials and Structures, Vol.20, No.4, 2011.

[3] 上野, 池畑, 山田, 発電素子および発電素子を備えた電 子装置"，特許 4905820

[4] T. Ueno, U-shape magnetostrictive vibration based power generator for universal use, Proc. SPIE 9806, Smart Materials and Nondestructive Evaluation for Energy Systems 2016, 98060E, 2016.

[5] 上野, 発電素子, 特願 2016-084065

[6] 福田結晶技術研究所 HP, http://www.fxtal.co.jp/

[7] Z. Deng and M. J Dapino, Influence of electrical impedance and mechanical bistability on Galfenol-based unimorph harvesters, Journal of Intelligent Material Systems and Structures, Vol. 28, pp.421-431, 2016.

[8] L. Wang and F. G. Yuan, Vibration energy harvesting by magnetostrictive material, Smart Materials and Structures, Vol. 17, pp.1-14, 2008.

[9] インタープラン HP, http://www.interplan.co.jp/

[10] 上野, 森山, 南谷, 磁歪式振動発電デバイスの耐久試験 結果, 第 26 回 MAGDA コンファレンス講演論文集, pp.399-400, 2017. 